\title{
EGYES FÖLDMINŐSÍTÉSI ÉS FÖLDPIACI TÉNYEZŐK ÖSSZEHASONLÍTÓ GAZDASÁGI ELEMZÉSE NÉMETORSZÁG ÉS FRANCIAORSZÁG PÉLDÁJÁN ${ }^{1}$ COMPARATIVE ECONOMIC ANALYSIS OF LAND VALUATION AND LAND MARKET FACTORS USING THE EXAMPLES OF GERMANY AND FRANCE
}

\author{
Naárné Tóth Zsuzsanna PhD ${ }^{1}$, Orlovits Zsolt ${ }^{2}$, Naár Antal Tamás ${ }^{3}$, Sőreg Ádám Pál ${ }^{4}$ \\ Gazdaság- és Társadalomtudományi Kar, Szent István Egyetem \\ ${ }^{1}$ egyetemi docens, ${ }^{2}$ adjunktus, ${ }^{3,4} \mathrm{PhD}$ hallgató \\ E-mail: Toth.Zsuzsanna@gtk.szie.hu, Orlovits.Zsolt@gtk.szie.hu, naaratamas@gmail.com, \\ adam.soereg@gmail.com
}

\section{Összefoglalás}

A földértékelésre vonatkozóan nincs egységes módszer használatban az Európai Unióban, értékelési mód és cél szerint különbözik. Ez problémát jelent a termőföld közgazdasági értékének és árának meghatározásában is. Kutatásunk során két uniós tagállam, Németország és Franciaország földértékelési és -minősítési rendszerét vizsgáltuk. Véleményünk szerint az ismertetett eljárások bizonyos elemei hasznosak lehetnek a hazai föld értékelési rendszer korszerüsítése során. A földértékelési rendszereken túl a termőföld piaci árát alakító közgazdasági tényezőket és a Németországban, illetve Franciaországban kialakult piaci árakat, valamint az azokat befolyásoló tényezöket is elemeztük.

\section{Summary}

There is no uniformly applied land valuation methodology in the European Union. Methods differ according to the aims and techniques of the valuation. Hence the determination of the economic value and the price of agricultural land is problematic. In our research the land valuation systems of two EU Member States (Germany and France) were examined. In our opinion, some elements of the described methods may be useful in the modernization of the Hungarian system of land valuation. In addition to the land valuation systems, the economic factors influencing the market value of agricultural land, the existing market prices and their influencing factors in Germany and France were analyzed.

Kulcsszavak: földminősítés, földértékelés, földár, közgazdasági tényezők, NUTS-2

JEL besorolás: R10, R11

LCC kód: HD28-9999

\section{Bevezetés}

A földértékelés, földminősítés kérdésével az elméleti és gyakorlati szakemberek a világ több területén is intenzíven foglalkoztak és foglalkoznak. Megállapítható, hogy a földértékelésre vonatkozóan nincs egységes módszer használatban az Európai Unióban, értékelési mód és cél szerint különbözik (Naárné, 2006; Naárné, 2009), ami problémát jelent a közgazdasági értékének és árának meghatározásában is. Munkánk során két uniós tagállam, Németország és Franciaország földértékelési és -minősítési rendszerét vizsgáltuk annak tükrében, hogy az

\section{争}

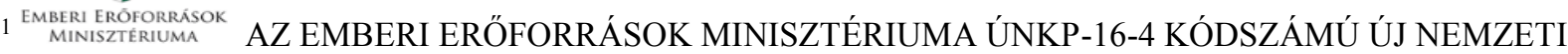
KIVÁLÓSÁG PROGRAMJÁNAK TÁMOGATÁSÁVAL KÉSZÜLT” 
ismertetett eljárások bizonyos elemei hasznosak lehetnek-e a hazai föld értékelési rendszer korszerüsítése során. A természeti viszonyokat kifejező talajértékszám, termőhelyi értékszám a földértékelésnek csak az egyik, elsődlegesen ökológiai szempontokat figyelembe vevő oldala. A másik a közgazdasági tényezőket kifejező értékszám. E kettő együttesen képes a föld valós értékét tejes egészében kifejezni. (Naárné et al., 2016) A közgazdasági tényezők értéknövelő vagy -csökkentő szerepet játszanak a földérték meghatározásakor. Kutatásunk során vizsgáltuk a földértékelési rendszereken túl a termőföld piaci árát alakító közgazdasági tényezőket és a Németországban, illetve Franciaországban kialakult piaci árakat, valamint az azokat befolyásoló tényezőket.

\section{Földminősítés és földértékelés}

A földminősítés egy olyan, jellemzően hatósági eljárás, amely során a termőföldek minőségi jellemzői az adott ország földügyi nyilvántartása számára megállapításra kerül. A földminősítésnek tehát két feladata lehet:

- a természeti-ökológiai jellegü minősítés (hazánkban ez a minőségi osztályba sorolással valósul meg), valamint

- $\quad$ a gazdasági minősítés (Magyarországon az aranykorona-érték megállapítása).

A természeti adottságokon alapuló minősítés során a talajokat azok különböző ökológiai tulajdonságai alapján sorolják be aszerint, hogy a vizsgált földterület művelési ágában való hasznosításához milyen potenciális adottságokkal rendelkezik. Ezzel szemben a gazdasági minősítés célja a termőföldnek a mezögazdasági hasznositása által várhatóan realizálható eredmény - nem közvetlenül pénzbeli - kifejezése. Egy adott ország földminősítési rendszere tehát akkor működik hatékonyan, ha hozzájárul az optimális termelési szerkezet kialakitásához, azaz annak eldöntéséhez, hogy a talajadottságok figyelembe vétele mellett mit és milyen ráfordítások (pl. talajerő-utánpótlás, melioráció) mellett érdemes rajta termeszteni.

A földminősítés nem azonos a földértékeléssel, mert ez utóbbi becslés nem hatósági nyilvántartási célból történik. A földértékelés a föld pénzben kifejezett aktuális piaci értékének megállapitására szolgál magánérdekből (pl. adásvételi vagy jelzálogkölcsön ügyletet megelőzően), illetőleg közérdekből (adó- és illetékfizetési kötelezettség alapjaként). Ez azonban nem zárja ki annak lehetőségét, hogy a földértékelés során a földminősítési adatokat ne lehetne hasznosítani.

Ha a földértékelés nemzetközileg ismert modelljeit vizsgáljuk, megállapítható, hogy azok inkább a piaci tényezőket (piacon érvényesülő keresleti és kínálati földár, haszonbérleti díj nagysága, ráfordítások költségigénye stb.) veszik alapul. Ilyen általános értékelései módszerek

- a piaci ár-összehasonlitáson alapuló,

- a äldbérleti dijak tökésitésével számoló, valamint

- a ráforditás- és hozamszámításon alapuló elvi módszerek, amelyek egymással kombinálhatóak is.

A földminősítés adatainak felhasználása ezzel szemben számos problémát felvet. 
a) Az egyik ilyen, hogy a földminősítés mezőgazdászok elemző, nagy tárgyi tudást, ismereteket, laboratóriumi kapacitásokat igénylö munkája kell hogy legyen, vagyis költségigényes. Mivel hatósági eljárásról van szó, megfelelö állami források nélkül nem kivitelezhető.

b) A másik szempont, hogy a keletkezett információk mennyire megbízhatóak. Ha a gyakorlatban az olyan ,,kiterjesztéses módszerek” válnak általánossá, amelyek a konkrét földrészlet minősítése helyett a velük határos, vagy a legközelebb fekvő, hasonló minőségű földrészletek értékein alapulnak, a minősítési eljárás szakmai elismertsége megkérdőjelezhetővé válik.

c) A nemzetközi összehasonlításon alapuló modellek hiányának további oka a földminősítési rendszerek eröteljes nemzeti karakterében keresendő. Az eltérő skálázási, pontszámítási és vizsgálati szempontjaiban is különböző rendszerek összevetése szinte lehetetlen feladat.

Munkánk során Németország és Franciaország földminősítési rendszerét vizsgáltuk annak tükrében, hogy az ismertetett eljárások bizonyos elemei hasznosak lehetnek-e a hazai földminősítési és -értékelési rendszer korszerüsítése során.

\section{Németország és Franciaország földminősítési rendszere}

A termőföld-minősítés termelési régiónként különböző módszerei használatosak Franciaországban. Jelenleg három fő modellt alkalmaznak, az egyes módszerek az ország különböző éghajlati és talajadottságokkal rendelkező övezeteiben jellemzőek.

Észak-Franciaországban a minősítési rendszert a gépesített, intenzív szántóföldi növénytermesztési rendszerekhez fejlesztették ki. Számos olyan talajjellemzőt választottak ki, amely közvetlenül befolyásolja a növény növekedését, vagy módosítja a gazdálkodási gyakorlatot. Minden egyes talajminőségi tényezőhöz bizonyos számú pontértéket párosítanak aszerint, hogy az adott növény igényeinek a talajtényező milyen mértékben felel meg. Az összesített maximális pontérték 1000 pont lehet. A kialakult aggregált pontérték tükrözi a talajtényezők termesztési szempontból való alkalmasságát. Ez az összesített pontszám adja a földminősítési értéket.

Közép-Franciaországban a minősítési módszert az ott jellemző, kevésbé intenzív növénytermesztési rendszerekre fejlesztették ki. Az értékelésbe bevont földminőség-jellemzők a vízkapacitás, a csírázási feltételek, a termőtalaj vastagsága, az oxigén- és tápanyag-ellátottság. A felsorolt jellemzők közötti súlyozást a térségi mezőgazdasági gyakorlat alapján határozzák meg, az összesített pontszám maximuma azonban egységesen 100 lehet.

A dél-franciaországi mediterrán térségekben alkalmazott földminősítési rendszerben az alábbi szempontokat és pontozási rendszert használják:

- $\quad$ a fontosabb földminőségi jellemzőket egyenként 20 pontos skálán, míg

- a kevésbé lényeges tényezőket egyenként 5 pontos skálán minősítik.

Bizonyos korlátozó tényezők jelenléte akár negatív pontszámot is eredményezhet. A végleges földminősítési pontérték a talajjellemzők és a vizsgált korlátozó tényezők pozitív és negatív pontszámainak összesítésével alakul ki. A maximális pontérték 70 pont. (Tar, 1999)

Németországban 1934-ben törvényben írták elő a talajok minősítésének kötelezettségét. A jelenlegi rendszer az '50-es évektől lépett életbe, amely hazánkban a Fórizsné-MátéStefanovits (1971) által kidolgozott (de bevezetésre nem került) 100 pontos rendszerhez hasonló, azzal a különbséggel, hogy Németországban a talajok osztályozása 7-100 pont között változik. A 100 pontos mintaterület Magdeburg környékén található, míg az ellenpólust a 
gyengébb talajok (15-20 pont), például Brandenburg tartomány egyes területei képviselik. (Gecse, 2000)

Az általunk vizsgált országokban alkalmazott földminősítési módszerek összehasonlítását az 1 . táblázat szemlélteti.

1. táblázat: A francia, német és magyar földminősítési módszerek

\begin{tabular}{|c|c|c|}
\hline ORSZÁG & $\begin{array}{l}\text { FÖLDMINŐSÍTÉS } \\
\text { IRÁNYA }\end{array}$ & $\begin{array}{c}\text { AZ ALKALMAZOTT } \\
\text { FÖLDMINŐ́SÍTÉSI MÓDSZER }\end{array}$ \\
\hline Franciaország & \multirow{2}{*}{$\begin{array}{c}\text { gépesített szántóföldi } \\
\text { növénytermesztési rendszerekhez } \\
\text { fejlesztették ki }\end{array}$} & \multirow[b]{2}{*}{1000 pontos rendszer } \\
\hline Észak-Franciaország & & \\
\hline $\begin{array}{c}\text { Közép- } \\
\text { Franciaország }\end{array}$ & $\begin{array}{c}\text { kevésbé intenzív } \\
\text { növénytermesztési rendszerekhez } \\
\text { fejlesztették ki }\end{array}$ & 100 pontos rendszer \\
\hline Mediterrán térségek & $\begin{array}{l}\text { egyes talajjellemzökre és } \\
\text { korlátozó tényezőikre terjed ki }\end{array}$ & 70 pontos rendszer \\
\hline Németország & $\begin{array}{c}\text { egységes } \\
\text { talajosztályozás } \\
\end{array}$ & 7-100 pontos rendszer \\
\hline \multirow[t]{2}{*}{ Magyarország } & $\begin{array}{l}\text { a) minőségi osztályba } \\
\text { sorolás }\end{array}$ & $\begin{array}{l}\text { becslőjárásonként és múvelési áganként } \\
\text { legfeljebb } 8 \text { minőségi osztály }\end{array}$ \\
\hline & $\begin{array}{l}\text { b) kataszteri tiszta jövedelem } \\
\text { (aranykorona) }\end{array}$ & $\begin{array}{c}\text { eredetileg pénzben kifejezett } \\
\text { jövedelmezőségi értékszám, } \\
\text { szántó esetén átlagosan } 20,1 \mathrm{AK} / \mathrm{ha}\end{array}$ \\
\hline
\end{tabular}

Forrás: saját szerkesztés

\section{A földpiaci árak meghatározása Németországban és Franciaországban}

A földérték megállapítását szolgáló piaci tényezők közül földár a legjelentősebb. A vizsgált tagországok értékelési rendszere - Magyarországgal összehasonlítva - annyiban specifikus, hogy mind Németország, mind pedig Franciaország üzemszabályozási rendszert müködtet, azaz a földet nem, vagy nem csak önmagában parcellaként, hanem a müvelés szempontjából összetartozó, egy gazdasági egységet képező földterületeket egy értékelési egységként is számon tartják. (Orlovits, 2008)

Németországban az ingatlan- és üzemértékelés általános és speciális elöírásait önálló törvényben (Bewertungsgesetz) szabályozzák, mégpedig a földforgalmi (adásvételi, ajándékozási, örökösödési) adók és illetékek megállapítása céljából. (Turner et al., 2006)

Az ún. üzemi egységérték gazdasági és lakóértékből tevődik össze, amelyből ez utóbbi az üzem területén esetlegesen található lakóház értékét jelenti. A gazdasági érték az adott üzem értéke, amelyet szükség esetén részekre bontva (parcellánként) is megállapítanak.

Az értékelési törvény alapján két értéket is meghatároznak:

a) az üzem, illetőleg egy konkrét parcella forgalmi értékét, amely piaci összehasonlításon alapul, és azt mutatja, hogy szokásos üzleti forgalomban az adott ingatlan értékesítése esetén mekkora árbevétel érhető el; valamint

b) a jövedelmezöségi értéket, amelyet kizárólag a 10000 euró feletti forgalmi értékü mezőgazdasági üzemre mint forgalmi egységre határoznak meg oly módon, hogy az adott gazdasági egység által tartósan realizálható nettó jövedelmet (az árbevételből levonva az üzemi ráfordításokat és egyéb elszámolható költségtényezőket) megszorozzák 
tizennyolccal. (Egyes tartományokban ez a szorzótényező nagyobb is lehet.) Az így kalkulált érték a gyakorlatban jóval a forgalmi érték alatt marad. Akkor alkalmazzák, ha az üzem hagyaték részét képezi (Erbhof). Mivel Németország egyes tartományaiban általánosan érvényesülö elv, hogy az Erbhof csak egy örökös kezébe kerülhet, az üzemet nem öröklö többi örököstárssal a jövedelmezőségi érték alapján, tehát egy lényegesen kedvezményesebb értéken kell elszámolni.

Németországban az adásvétel során a felek megegyezése révén kialkudott piaci vételár nagyságát előzetesen az illetékes tartományi hatóság is megvizsgálja. Amennyiben a szerződésben megállapított vételár jelentösen eltér a helyben szokásos piaci viszonyoktól, és egyben hátrányos következményekkel jár a helyi üzemszerkezet alakulására, úgy a tranzakció létrejöttét a földügyi szerv megakadályozza. Önmagában a túlzottan magas (vagy éppen alacsony) vételár még nem megtagadási ok, csak ha ez az adott térségben tendenciaszerïen érvényesül. Németország Svájccal például éppen emiatt kötött egy különmegállapodást, a két ország határövezetében lévő termőföldekre nézve. Ennek lényege, hogy a határmenti településeken legfeljebb az elözetesen hivatalosan közzétett piaci összehasonlitó ár 120\%-án lehet termőföldet, illetőleg üzemet értékesíteni. Az intézkedés célja, hogy a tökeerős svájci termelők ne verjék fel az árakat a helyi gazdálkodók rovására. (Grimm, 2010)

Németországban a parcellák piaci forgalmának további akadályai is vannak. Ezek közül kiemelendö, hogy a földügyi hatóság akkor sem engedélyezi egy földterület értékesítését, ha az adásvételi ügylet hatására az érintett mezögazdasági üzem elveszitené életképességét. Ez a megtagadási ok tehát akkor lehet hivatkozási alap, ha egy üzem területéből leválasztott földrészlet önálló értékesítésére kerülne sor. A németországi gyakorlat is rávilágít arra, hogy nemcsak önmagában a földterületek, hanem az üzemegységek komplex értékelési rendszerének kidolgozására is szükség volna.

A haszonbérleti díj tökésítésével kalkulálható föld- és üzemérték-megállapítás kapcsán kiemeljük, hogy Németországban a haszonbérleti díj a piaci viszonyok alapján meghatározott. A szerződések tartalmi vizsgálata során a hatóság csak akkor élhet kifogással, ha aránytalan a bérleti díj nagysága a bérlet tárgyát képező földrészlet minőségéhez, illetve az üzemi leltár teljes értékéhez viszonyítva. (Grimm, 2010)

Franciaországban a piaci (forgalmi) értéknek van kiemelt jelentősége, de öröklés esetén ott is alkalmaznak egy kedvezményes értékelési módozatot. Az üzemet ténylegesen öröklö, bíróság által kijelölt örökösnek ugyanis joga van a forgalmi értékből az ún. visszamenöleges munkabér (salaire diféré) beszámításra. A szabályozás abból indul ki, hogy a birtokon szüleivel fỏállásban dolgozó testvér a szülök haláláig gyakorlatilag munkabér nélkül gazdálkodott, miközben a többi örökösnek módjában állt fóállású munkavállalóként másutt elhelyezkedni. Ezért a hagyatéki eljárás során visszamenőleg meg kell állapítani az üzem örökösének elmaradt munkabérét, amit le kell vonni az üzem forgalmi értékéből. Így viszonylag kis birtok, vagy a szülökkel együtt töltött hosszú időszak esetén elöfordulhat, hogy az üzemet öröklőnek nem is keletkezik az örököstársaival szemben jelentős elszámolási kötelezettsége. (Somogyi, 2005) 
A francia szabályozási környezet a földtulajdonszerzés szempontjából megengedőnek tünik, ez azonban csak első látásra igaz. A földtulajdonos szabad rendelkezési joga ugyanis több szempontból is korlátozott (Orlovits-Kovács, 2015):

a) Franciaországban - a német szabályozással szemben - nem a tulajdonszerzés, hanem $a$ föld használatba vétele kötött hatósági engedélyhez, az viszont jogcímtöl függetlenül, azaz a használatbavétel ténye számít, és nem az, hogy a föld a gazdálkodó tulajdonában van-e, vagy haszonbérli azt. Így könnyen elöfordul olyan helyzet, amikor egy földtulajdonos müvelési engedély hiányában a saját tulajdonában álló földterületét nem lesz jogosult maga megmüvelni, hanem haszonbérbe adni kényszerül. Ennek egyik oka az lehet, hogy a szóban forgó földrészlet túl messze van a bejelentett üzemközpontjától, vagy az is, ha már túlságosan nagy területen gazdálkodik, így veszélyezteti a többi környékbeli gazdálkodó fennmaradását.

b) A francia jog elsődlegesen a termőföld haszonbérletén alapuló gazdálkodást preferálja abból a közgazdasági megfontolásból kiindulva, hogy a föld megvásárlása az agrárüzem számára aránytalanul nagy tőkelekötést jelent, és így csak a korszerübb gazdálkodást eredményező müszaki fejlesztés elől venné el a forrásokat. A francia szabályozás tehát $a$ haszonbérlők jogbiztonságát védi a tulajdonos bérleti dijban megnyilvánuló járadékigényével szemben. Ennek érdekében hatósági úton, a mezőgazdasági termények piaci árához kötötten évente közzéteszik az irányadó haszonbérleti díj minimális és maximális mértékét. Ezt mindig az új szerződésekre nézve kell betartani, és a szerződő felek csak az alsó és felső limiten belüli díjban állapodhatnak meg. A haszonbérleti díj mértékét 9 évente vizsgálhatják csak felül.

E két szabályozási sajátosság hatása az lett, hogy pusztán befektetési célból senki sem preferálja a földvásárlást Franciaországban, ezért a németországinál tartósan alacsonyabb egyensúlyi földárakkal kell számolni. Ennek legfőbb okai következők:

- a haszonbérleti díj hatóságilag alacsony szinten tartása a termőföldről más értéktárgyak felé mozdította a nem szakmai befektetőket,

- a gazdálkodókat pedig a saját üzemük körüli földek megvásárlásában teszi csak érdekeltté, azaz erőteljesen lokalizálta a piaci pozíciójukat.

\section{A termőföld piaci árát alakító közgazdasági tényezők áttekintése}

A továbbiakban a termőföld árát alakító legfontosabb tényezőket vizsgáljuk az Európai Unió két országában, Franciaország és Németország területén. Ezen országok közös jellemzője, hogy jelentős agrár- és élelmiszergazdasági belső piaccal rendelkeznek, hiszen népességük együttesen meghaladja a 145 millió főt. Ez az Európai Unió teljes népességének közel 30 \%-a. Nagy kiterjedésük miatt mindkét ország európai viszonylatban is jelentős nagyságú mezőgazdasági müvelés alatt álló területettel rendelkezik, Franciaországban az Eurostat 2013. évi adatai alapján mintegy 27,7 millió hektárt, míg Németországban 16,7 millió hektárt műveltek. Az EU összes mezőgazdasági használatban álló földterülete 174 millió hektár. Míg Magyarországon az uniós mezőgazdasági területek csupán 2,6\%-a, mintegy 4,6 millió hektár található, addig Franciaországon belül van az EU termőföldvagyonának 16\%-a, Németországon belül mintegy $10 \%$. Az Egyesült Királyság várható kilépése után a franciaországi termőföldek, ezzel pedig a francia mezőgazdasági vállalkozások gazdasági és érdekérvényesítése erejének súlya az EU-n belül tovább növekedhet, megközelíti majd a 18\%-ot. A 2. táblázat a müvelhető területek megoszlását szemlélteti Franciaország, Németország és az EU tekintetében. 


\section{2. táblázat: Müvelhető területek megoszlása Franciaországban, Németországban és az} EU egészében (2013)

\begin{tabular}{lccccccccc} 
& $\begin{array}{l}\text { Összes } \\
\text { terület }\end{array}$ & \multicolumn{7}{c}{ Mezőgazdasági művelés alatt álló terület (ezer ha) } \\
& & olivaültetvén & gyümölcsö & egyé \\
& (ezer hektár) & összes & szántó & legelő & y & szőlő & s & b \\
\hline Franciaország & 55170 & 27739 & 18466 & 8242 & 13 & 794 & 182 & 42 \\
Németország & 35711 & 16700 & 11876 & 4621 & 0 & 99 & 63 & 40 \\
& & 174 & 104 & 59 & & 2 & & \\
Európai Unió* & 437847 & 238 & 115 & 564 & 4156 & 910 & 2465 & 1028 \\
\hline
\end{tabular}

\begin{tabular}{lcccccccc} 
& Mủvelhető & \multicolumn{7}{c}{ összetétel mủvelési ágak szerint (\%) } \\
& terület (\%) & összes & szántó & legelő & olivaültetvén & szölő & gyümölcsö & egyé \\
b
\end{tabular}

*Mezőgazdasági összterület a két mediterrán szigetország (Málta és Ciprus) termőföldjei nélkül Forrás: Eurostat (2016)

Látható, hogy mindkét ország esetében, akárcsak az EU egészében, legfontosabb mủvelési ág a szántó. Franciaországban és Németországban a szántóföldek az összes müvelt terület 67-71\%át adják, amely arra utal, hogy ebben a két országban a szántóföldi növénytermesztési ágazat agrárszektoron belüli relatív súlya meghaladja az uniós átlagot. Ezt erősíti, hogy a legelőként funkcionáló földterületek aránya a két országban elmarad a 34,2\%-os európai középértéktől. Más müvelési ágak közül a két ország vonatkozásában egyedül a szőlöültetvényeket említhetjük, Franciaország adja ugyanis az EU szőlő- és bortermelésének közel 30\%-át. A mediterrán országrészben a szőlő mellett - legalábbis európai viszonylatban - fontos művelési ág még az olivaültetvény.

A termőföld átlagos árszintjének alakulását müvelési ágak nélküli bontásban vizsgáljuk, ebből adódóan a NUTS-2 európai statisztikai régiókra jellemző átlagár elemzésünkben fellelhető területi különbségeit és szóródását döntő részben a szántóföldek értéke határozza meg.

Franciaország és Németország között számottevő árkülönbség mutatkozik az országokon belüli regionális eltéréseken felül is. A német átlagár 2014-ben 19754 euró, míg a franciaországi 7 371 euró volt hektáronként. Általánosságban megfigyelhető, hogy a termőföld ára a gazdasági centrumrégiókban a legmagasabb. Németországban a leginkább kiemelkedő termőföld-árak Bajorországban és Észak-Rajna-Vesztfáliában fordultak elő, mindkét térségben kevéssel 40 000 euró/hektár felett alakultak a 2014. évben. A volt keletnémet tartományok (például SzászAnhalt, Thüringia, Brandenburg) földárai a mai napig lényegesen elmaradnak a nyugatnémet régiók árszínvonalától. Thüringia az egyetlen olyan német szövetségi tartomány, ahol 2014-ben is 10000 euró alatt maradt a termőföld átlagos hektáronkénti piaci ára. Érdekesség, hogy a német gazdaság két centrumtérsége közötti „félperiférikus övezetet” a földárak alakulását szemléltető térkép is megjeleníti, az északnyugati rész és Bajorország közötti sávban rendre 10 ezer és 15 euró/hektár közötti árakkal találkozhatunk. Az 1. ábra a termöföld átlagos piaci értékét mutatja be NUTS-2 régiónként Franciaországban és Németországban. 


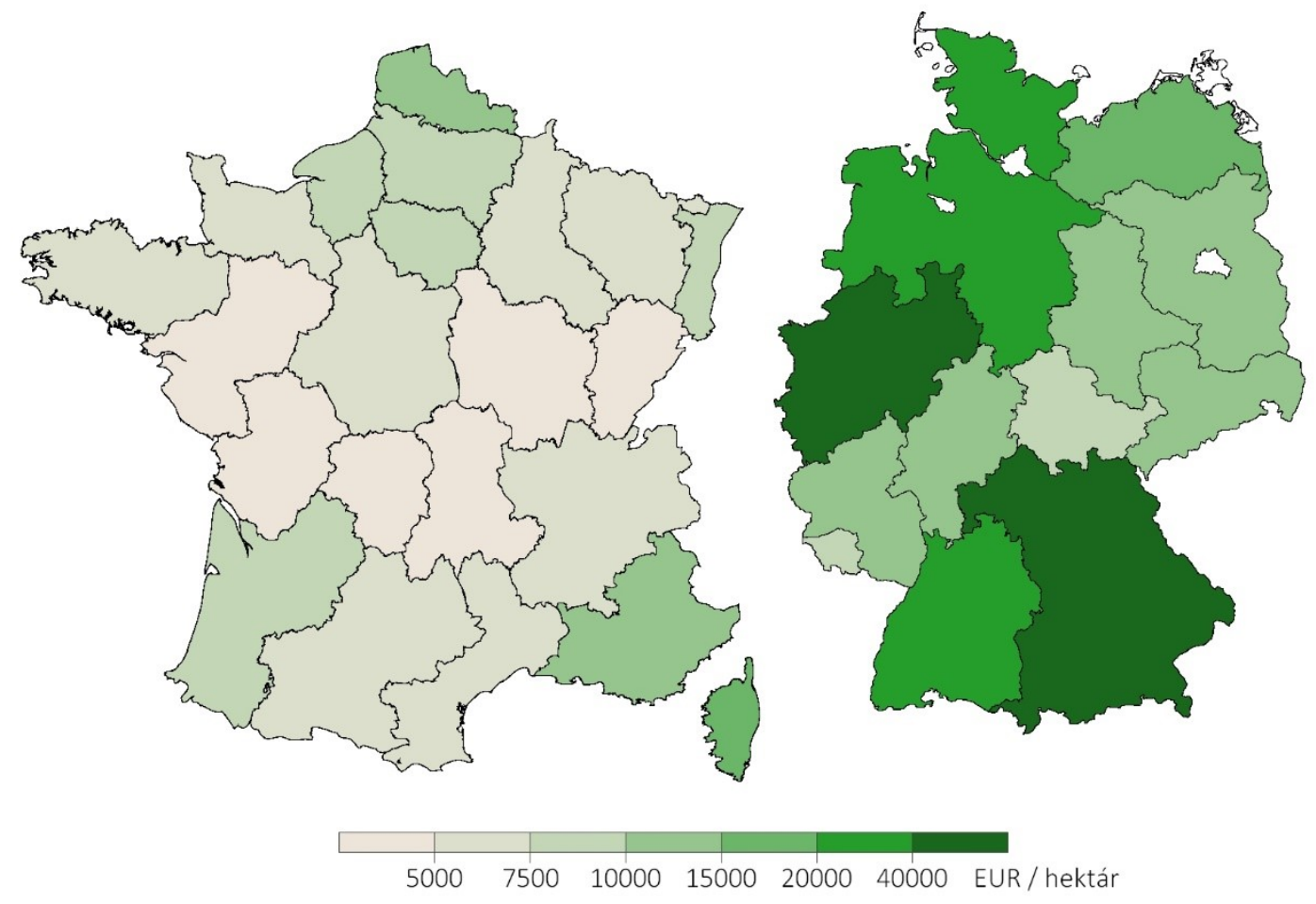

\section{1. ábra: A termőföld átlagos piaci értéke NUTS-2 régiónként Franciaországban és Németországban (2014)}

Forrás: saját szerkesztés Safer-SSP-Terres d'Europe (2015), Statistiches Bundesamt Deutschland (2015), Bodenverwertungs- und verwaltungs GmbH (2015) adatai alapján

Franciaországban az országos átlagnál magasabb árakkal lehet találkozni a Párizsi-medencében (Ile-de-France), Párizstól északra, egészen Calais-ig, Elzász-Lotaringia térségében a német határ mentén, illetve a délkeleti mediterrán partvidéken Provence - Cote d'Azur tartományban. Az itt felsorolt térségekben hektáronként 8-13 ezer euró a jellemző földár. A legmagasabb árszint Franciaországon belül Korzikában tapasztalható, ahol 2014-ben az átlagos hektárár 17 900 euró volt.

Franciaország belső területein - a párizsi centrumtérségtől eltekintve - a termőföldárak európai összehasonlításban alacsonyak. A Franche-Comté, Bourgogne, Limousin régiókban tapasztalható 3000-4000 euró/hektáros piaci átlagár - jórészt a francia szabályozási sajátosságoknak köszönhetően - lényegében a hazai földárak szintjével tekinthető azonosnak.

A termőföld értéke Franciaországban és Németországban a 2014. évi árszintek és az Eurostat 2013. évi agrárszektor-specifikus és általános gazdasági mutatóival számottevő összefüggést mutat.

A német és francia NUTS-2 régiókon belül megfigyelhető, hogy azokban a tartományokban, ahol magas a bérlők/haszonbérlők által megművelt területek aránya az összes mezőgazdasági céllal hasznosított földterületen belül, az árak számottevően alacsonyabbak lesznek. A termőföld iránt nagyobb vevőoldali kereslet ott mutatkozik, ahol a bérleti jogviszony gazdasági jelentősége kisebb, a gazdák általában saját földjeiket müvelik, emiatt a birtokméret növelésére egy-egy gazdálkodónak leginkább földvásárlással nyílik lehetősége. Ezzel szemben azokban a 
régiókban, ahol a bérleti piac élénk, a földforgalom intenzitása kisebb, és jellemzően az árak is alacsonyabban alakulnak.

A termőföld értékének összeurópai vizsgálata azt mutatja, hogy makrogazdasági szempontból egy erős középbirtokrendszer vezet a termőföld mint erőforrás leginkább optimális felhasználásához. ${ }^{2}$ A túlzottan szétaprózódott, kisméretü birtoktestek műveléstechnikailag előnytelenek, és ebben az esetben a gépi müvelésböl adódó méretgazdaságosság sem érvényesül megfelelően. Ugyanakkor a 100 hektár feletti birtokok túl magas aránya csökkenti a termőföld iránt regionális szinten mutatkozó érdeklődést, ezzel a földárak is csökkennek, az alacsonyabb árszint mellett pedig olyan mezőgazdasági ágazatok kerülnek túlsúlyba, amelyek hektáronként alacsonyabb értéket állítanak elő (szántóföldi növénytermesztésen belül is kis jövedelemintenzitású kultúrák). Az egységnyi területen magasabb jövedelmet előállítani képes állattenyésztés és kertészet szerepe a nagyobb birtoktestek által uralt térségekben csekély marad.

A tagországok földhasználatának állami szabályozása a korábban történelmileg kialakult birtokpolitikán alapszik. (Burgerné, 1998) A nyugat-európai tagországok a XVIII. századtól kezdve sorozatos birtokreformokkal alakították át mezőgazdaságukat a korábbi nagy feudális birtokokból önálló családi kisbirtokokká. Németország és Franciaország földbirtok-politikája is ezt a folyamatot támogatta: egyrészt a nagybirtokok kialakulását igyekeztek megakadályozni (a birtokforgalomra és a bérletekre vonatkozó korlátozásokkal), másrészt sajátos öröklési törvényekkel gátolták a meglevő birtokok életképtelen elaprózódását. A kisbirtokok életképességét támogatják a Németországban tartományonként is eltérő, sajátos öröklési törvények (pl. Höferecht, Anerbrecht) mellett a birtokfelosztás korlátozása és a minimálisan egybetartandó birtokméret elöírása is. (Kelemen, 2007)

A nemzeti-tartományi szintü szabályok sok esetben ellentétbe kerültek az EU szabad piaci elveivel. Az uniós tagországok mintegy harmadának szabályozása (köztük Franciaországnak és Németországnak is) a kistulajdonosok gazdálkodását támogatja. A nagybirtokok kialakulásától tartva a birtokszabályozás keretében a kisbirokok életképességét igyekeztek elősegíteni, ennek érdekében korlátozták:

- a megszerezhető birtoknagyságot,

- $\quad$ az egy gazdálkodó által birtokolható gazdaságok számát,

- $\quad$ a gazdaság központjától távol fekvő birtokrész szerzését,

- a nem mezőgazdasági foglalkozású, nem helyi lakosok, valamint a tőkés társaságok birtokszerzését. (Kelemen, 2007)

A 2. ábra a földár és az egyes gazdasági mutatók közötti térségi összefüggéseket szemlélteti.

\footnotetext{
${ }^{2}$ Hazánkban a mezőgazdaság döntően magántulajdonra épül és vegyes üzemrendszerü (Káposzta, 2016).
} 

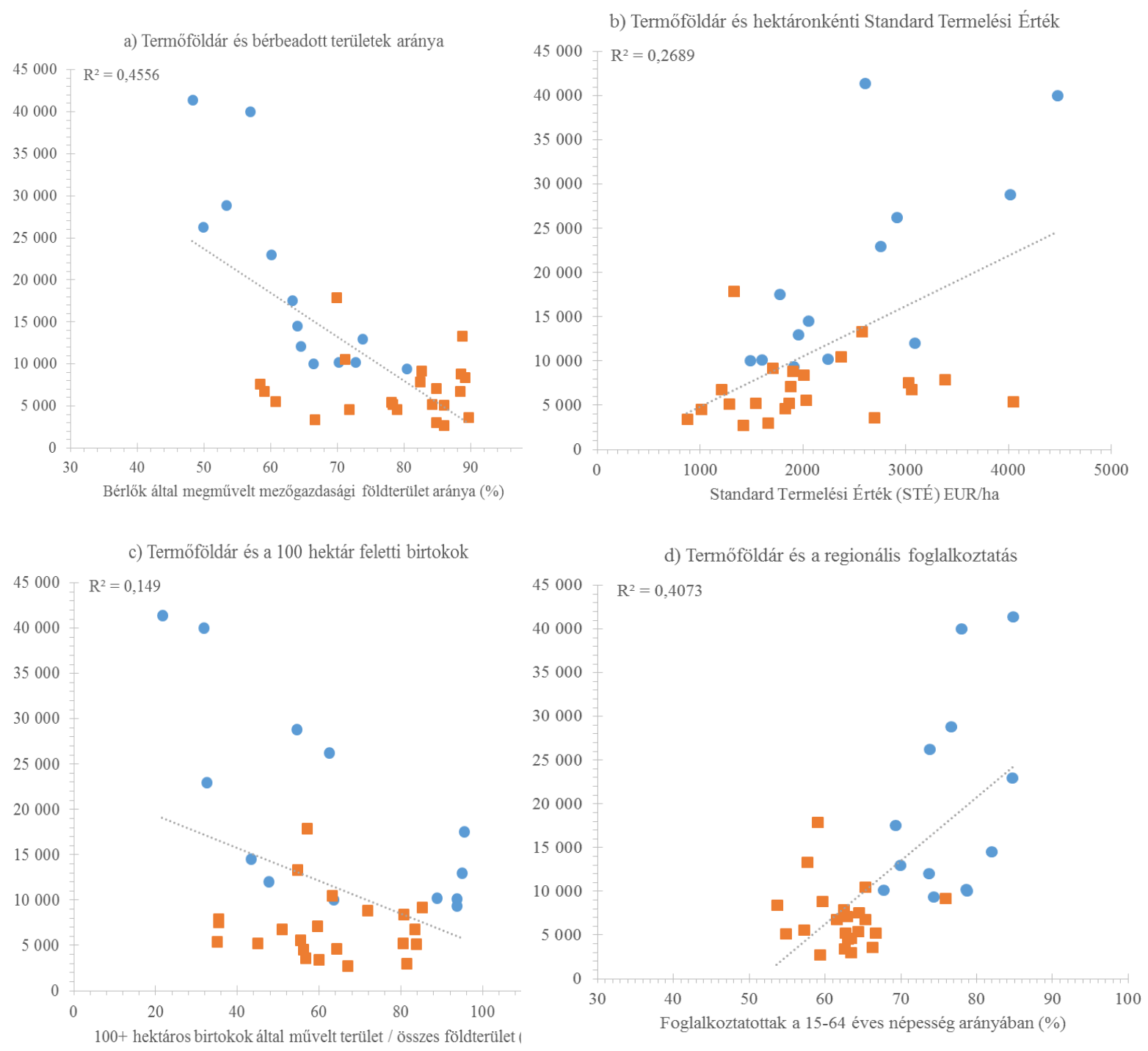

кек коr: nemet tartomanyok, narancssarga negyzet: francia tartományok

2. ábra: A termőföldár és az egyes gazdasági mutatók közötti térségi összefüggések Forrás: saját számitás Eurostat (2016) alapján

A földárak jellemzően Németországnak azokban a tartományaiban mutatkoznak a legmagasabbnak, ahol a 100 hektárnál nagyobb birtoktestek részesedése az összes mezőgazdasági földterületből legfeljebb $25-35 \%$. Franciaország alacsony árszínvonalú belső területein a 100 hektár feletti nagybirtokokhoz kapcsolható az összes megmüvelhetö terület 7080\%-a. Ez alól az összefüggés alól némileg kivételt képeznek Németország keleti tartományai, ahol a nagyobb üzemterületü gazdaságok jelenléte a szocialista rendszer kollektivizációjának öröksége. Itt az árak Franciaország egyes területeihez képest magasabbak, ugyanakkor éppen a nagybirtokok elterjedtsége lehet az akadálya annak, hogy a keletnémet árak a Németország nyugati részei megfigyelt szint irányába konvergáljanak.

\section{Következtetések, javaslatok}

Munkánk során elemeztük Németország és Franciaország földminősítési rendszerét, valamint a két ország földpiaci sajátosságait a szabályozás és az áralakulás szempontjából. 
A földminősítési rendszer vizsgálata kapcsán arra a megállapításra jutottunk, hogy az ismertetett eljárások bizonyos elemei hasznosak lehetnek a hazai, elavultnak számító földminősítési rendszer korszerüsítése során.

A földár és az azt befolyásoló szabályozási tényezők összehasonlítása alapján megállapítottuk, hogy bár az állami beavatkozás módszerei (előzetes hatósági engedélyezés rendje, a szokásos piaci ártól jelentősen eltérő földforgalmi ügyletek kizárása) a két országban hasonlóak, a beavatkozás mélysége jelentösen különbözik, és ez a földárakra is eröteljesen rányomja a bélyegét. A francia modell a földpiacot „a gazdák piacává” tette. Szinte csak a helyi gazdálkodók érdekeltek a termőföld megvásárlásában, mégpedig azáltal, hogy az állam eröteljesen lokalizálta a föld iránt megnyilvánuló keresletet, és a földböl kinyerhetö abszolút (tulajdoni) járulék mértékét.

A földárat befolyásoló közgazdasági tényezök kutatása során megállapítottuk, hogy míg Magyarországon az uniós mezőgazdasági területek csupán 2,6\%-a, addig Franciaországon belül van az EU termőföldvagyonának 16\%-a, Németországon belül mintegy 10\%. Az Egyesült Királyság várható kilépése után e két, legjelentősebb agrárpotenciállal rendelkező tagállam relatív súlya az EU-n belül tovább növekszik. Franciaország és Németország között számottevő termőföldár-különbség mutatkozik az országokon belüli regionális eltéréseken felül is, ami jelentős részben intézményi-szabályozási tényezőkre vezethető vissza.

A német és francia NUTS-2 régiókon belül megfigyelhetö, hogy azokban a tartományokban, ahol magas a bérlők/haszonbérlők által megmüvelt területek aránya az összes mezőgazdasági céllal hasznosított földterületen belül, a földárak számottevően alacsonyabbak.

A termőföld értékének összeurópai vizsgálata során megállapítható, hogy makrogazdasági szempontból egy erős középbirtokrendszer vezet a termőföld mint erőforrás leginkább optimális felhasználásához.

\section{Irodalomjegyzék}

1. Burgerné G. A. (1998): Földhasználati és földbirtok-politika az Európai Unió országaiban I.-II., Statisztikai Szemle, 76. évf. 4-5 sz., 1998. április-május, ISSN 00390690

2. Fórizsné - Máté F. - Stefanovits P. (1971): Talajbonitáció - földértékelés. - Az MTA Agrártudományi Osztályának Közleményei 30. (3) 359-378.p.

3. Gecse M. (2000): Hogyan alakul a földpiac ma Magyarországon? Agronapló, IV. pp. 2021.

4. Grimm, Ch. (2010): Agrarrecht München, C.H.Beck Verlag 335p.

5. Káposzta J. (2016): Regionális összefüggések a vidékgazdaság fejlesztésében. Studia Mundi - Economica 3:(1) p 55. ISSN 2415-9395

6. Kelemen K. (2007): „Fából -vaskarika”. Kísérletek a földpiac-földár pótlására 1945-től az ezredfordulóig Magyarországon. Doktori (PhD) értekezés. Pázmány Péter Katolikus Egyetem. 179 p.

7. Naárné T. Zs. (2006): A földértékelés gyakorlata az Európai Unióban. Gazdálkodás 50:(16) pp. 114-118., ISSN 0046-5518

8. Naárné T. Zs. (2009): A termőföld közgazdasági értéke és piaci ára. Budapest, Agroinform Kiadó. 186 p. ISBN: 978-963-502-816-0

9. Zs. Tóth-Naár - M. Molnár - T. Naár - S Vinogradov (2016): Capitalization of direct payments into agricultural land prices and land rents in Hungary. In: Gyenge Balázs, Kozma Tímea (szerk.). Challenges in Process Management: Decision points, network systems and strategies in practice. 152 p. Gyöngyös: Károly Róbert Kutató-Oktató Közhasznú Nonprofit Kft., 2016. pp. 140-148. ISBN: 978-963-9941-95-3

10. Orlovits Zs. (2008): A mezőgazdasági üzem fogalmának agrárjogi értelmezése Gazdálkodás, 52. évf. 4. sz. 368-374.pp. ISSN 00390690 
11. Orlovits Zs. - Kovács L. (2015): A mezőgazdasági üzemszabályozás adaptációs lehetőségei nyugat-európai modellek alapján Gazdálkodás, 59. évf. 2. sz. 127-141.pp. ISSN 00390690

12. Somogyi N. (2005): A mezőgazdasági birtokrendszer átalakulása Franciaországban Gyakorlati Agrofórum, 16.évf. 12.sz. pp.59-61.

13. Tar F. (1999): Termőföldértékelés az Európai Unióban. In: Michéli - Stevanovits (szerk.): A talajminőségre épített EU-konform földértékelés elvi alapjai és bevezetésének gyakorlati lehetősége. Budapest: Agroinform Kiadó, pp. 19-42.

14. Turner, G. - Böttger, U. - Wölfle, A. (2006): Agrarrecht Frankfurt am Main, DLG-Verlag $346 p$. 